\title{
Understanding Implementation of Patient Safety Goals Framework at Inpatient Unit of Ciracas General Hospital, Indonesia
}

\author{
Aditya Galatama Purwadi ${ }^{1}$, Wahyu Sulistiadi $^{2 *}$, and $A l$ Asyary ${ }^{2}$ \\ ${ }^{1}$ Ciracas General Hospital, Jakarta - Indonesia \\ ${ }^{2}$ Faculty of Public Health, University of Indonesia, Depok - Indonesia
}

\begin{abstract}
Introduction: This study aimed to determine the application of Patient Safety Goals (PSGS) according to formal regulation of WHO Patient Safety and Joint Commission International (JCI) that set by Ministry of Health Act - in Inpatient Unit of Ciracas General Hospital. Materials and Methods: The study was conducted in May-June 2017 through qualitative approach. The FGDs were conducted with nurses who were served in the inpatient unit, while in-depth interview was conducted to the informants by considering positions, duties and functions, and knowledge of Ciracas Hospital. Results: This study obtains indicators of PSGS that have not well-fully run in the Ciracas General Hospital inpatient unit. There was one indicator of PSGS which was PSGS 4; surely of fits procedure, that not entirely asses as of its infrastructure had not finished build. Fostering patient safety culture and to follow patient safety goals framework are the essential thing to be improved in inpatient unit. Conclusion: Patient safety in Ciracas General Hospital has become the genuine concern after this healthcare facility was improved from a primary healthcare facility before. However, there were several aspects that had no change with this healthcare facility transformation including building to focus on health care delivered.
\end{abstract}

Keywords: patient safety; hospital administration; hospital management; medication error; Indonesia.

\section{Introduction}

Hospital patient safety is a system where the hospital makes patient care safer [1]. The system includes assessing risk, identifying and managing matters related to patient risk, conducting incident analysis and reporting, learning from incidents, and following up and implementing solutions to minimize risk [1-3]. The system is expected to prevent the occurrence of injury caused by errors from carrying out an action or not taking action that should have been done [4].

Patient safety is a strategic priority [5, 6]. AHA stipulates measurable improvements in medication safety as its main target. To achieve this goal, AHA collaborates with the Institute for Safe Medication Practices (ISMP) to disseminate ISMP medication selfassessment to all hospitals in the United States.

The Provincial Government of Jakarta currently has five Class A, B, and C general hospitals, one special hospital, and twenty Class D general hospitals which are the transformation of health centers [7]. Determining whether health centers should become Class D general hospitals has been started since 2013 because of the national health insurance program and planned to start in early 2014, which increased the fifth visit of the Provincial Government of Jakarta, causing a long queue of patients who came for treatment which limited ED observation rooms, hospitalization, and intensive-care units, which became problems that must be resolved immediately at that time [8]. Responding to these problems, the Provincial Government of Jakarta through the Jakarta Provincial Health Office organized all heads of health centers and formed an acceleration team for the establishment of Class D general hospitals, which were divided into five regions [7,8]. Class $\mathrm{D}$ hospitals are expected to reduce the upsurge of patients and the burden in Class A, B, and C hospitals so that patient services can be improved.

With the publication Governor Regulation No. 1024 of 2014 concerning the Establishment of the Health Center to become a Class D General Hospital and Governor's Regulation No. 128 of 2014 concerning the Establishment of Class D General Hospital Organizations and Work Procedures $[9,10]$. As a pilot project, the Class D General Hospital was established at several health centers. The Class D General Hospital of Ciracas is one of 15 Class D hospitals that originated (transformed) from the Ciracas Health Center. This change is not only in the name but also in all of its activities. Ciracas Health Center's activities were initially a combination of public and individual healthcare efforts, where public health efforts were

\footnotetext{
* Corresponding author: wahyufphui $@$ gmail.com
} 
prioritized. However, while being transformed into a hospital, the priority of activities changed to individual healthcare efforts with a primary focus on increasing the capacity of inpatient beds to reduce the burden on Class $\mathrm{A}, \mathrm{B}$, and $\mathrm{C}$ hospitals as they are often overwhelmed when accommodating patients who are indicated to be treated./

Ciracas Hospital's facilities and infrastructure and all its medical and non-medical human resources at the time of its establishment came from the Ciracas Health Center; hence, the upgrading of the status of the Ciracas Health Center to Ciracas General Hospital has many problems, which can potentially cause medical errors. The facilities and infrastructure that come from the healthcare center are certainly not following the hospital building standards because it was not originally designed to be a hospital.

The preliminary study indicates some problems, for example, the position of inpatient is located on the second floor and is planned to be moved to the third floor and partly extended to the fourth floor [8]. However, Ciracas Hospital has no ramp as an evacuation path for patients who cannot walk if there are emergency conditions (fires, earthquakes, etc.) [8]. Ciracas Hospital has a narrow emergency room and a separate closed observation room with a doctor's examination room for ED patients. This makes it difficult for doctors to watch their patients [7]. Ciracas Hospital initially had approximately 80 staff, all of whom came from the health center [7]. They had a working style and mindset that was different from those who work in hospitals. For example, the competence of medical and paramedical personnel who served in the ED unit was of special concern because there was no ED unit at the health center. This becomes an even more complex problem due to the lack of good planning according to the needs of Ciracas Hospital. For example, due to time constraints in entering the budget, consultations for Medical Device and Medication are conducted by another Hospital Specialist who turns out to be less appropriate compared with the Poly Specialist serving at Ciracas Hospital. This study examines the implementation of patient safety goals (PSGS) at The Ciracas Hospital Inpatient Unit.

\section{Materials and Methods}

This study will evaluate the application of PSGS based on regulations [11]. This target setting refers to the Nine Life-Saving Patient Safety Solutions also used by the Indonesian Hospitals Association and from the JCI [12]. PSGS includes achieving the following: accuracy of patient identification; improved effective communication; improved drug safety that needs to be watched out; right-location certainty, right-procedure surgery, right-patient surgery; reducing the risk of infection related to health services; and reducing the risk of falling patients.

Qualitative approaches involve in-depth interviews with informants, focus group discussions (FGD), and observations. The FGDs were conducted with nurses who were served in the inpatient unit of Ciracas
Hospital. Observations were made by examining documents related to the implementation of objectives at Ciracas Hospital (medical records, internal incident reports of Ciracas Hospital), taking photos of the situation and conditions of Ciracas Hospital facilities and infrastructure that are directly related to patient services, and requesting testimony from patients/family of patients who were treated in Ciracas Hospital.

In-depth interviews of informants at Ciracas Hospital were conducted. The informants were selected by considering positions, duties and functions, and knowledge, so that they could provide an overview of the implementation of patient safety goals, as well as efforts made to prevent medical error incidents in the unit (Table 1).

Table 1. List of in-depth interview informants

\begin{tabular}{|c|}
\hline Informant \\
\hline Director of \#\# \\
\hline $\begin{array}{c}\text { Head of Nursing } \\
\text { and Medical } \\
\text { Support Section }\end{array}$ \\
\hline $\begin{array}{c}\text { Head of } \\
\text { Implementing Unit } \\
\text { for Inpatient and } \\
\text { Special Space }\end{array}$ \\
\hline $\begin{array}{c}\text { Head of Nursing } \\
\text { Executing Unit }\end{array}$ \\
\hline $\begin{array}{c}\text { Responsible for } \\
\text { Inpatient }\end{array}$ \\
\hline General \\
Practitioner/Medic \\
al Committee \\
\hline
\end{tabular}

To fulfill research ethics, the researchers obtained a letter of application for research permission at Ciracas Hospital from the Director of Ciracas Hospital. Before conducting in-depth interviews with informants, researchers always read the guidelines for in-depth interviews with information to obtain informed consent. The data was confidential and only researchers can access the data. This study also passed the Ethics Review of the \#\#\#: 299/UN2.F10/PPM.00.02/2017.

\section{Results}

Ciracas Hospital is a DKI Jakarta Province Class D hospital, which was first accredited in the 2012 version by KARS and successfully graduated in March 2016. Ciracas Hospital underwent the first verification survey in March 2017. The Patient Safety Program at Ciracas Hospital contained in the PSGS Working Group (Patient Safety Target) is following the KARS Accreditation Working Group.

The inpatient unit already has several service quality targets, related to the application of both PSGS and other administrations. These quality objectives are prepared by the inpatient unit itself to monitor and evaluate the course of patient services in the inpatient unit. The selection of topics used as quality targets is usually 
based on what is important or should always be monitored regularly (hand washing, PPE use, etc.) and what is considered to be a weakness in the inpatient unit (usually related to problems administration). The selected quality objectives will be submitted to the Ciracas Hospital quality committee to be discussed and determined to be quality targets in the inpatient unit. This quality goal can change if the achievement has reached or exceeded the target for 1 year or can increase according to the needs in the inpatient unit or management policy (Table 2).

Table 2. Quality Objectives of \#\# in 2017

\begin{tabular}{|c|c|c|c|c|c|c|c|c|}
\hline \multirow{2}{*}{$\begin{array}{l}\mathbf{N} \\
\text { o. }\end{array}$} & \multirow{2}{*}{$\begin{array}{c}\text { Quality } \\
\text { Goals }\end{array}$} & \multirow{2}{*}{$\begin{array}{c}\text { Targ } \\
\text { et }\end{array}$} & \multirow{2}{*}{$\begin{array}{c}\text { Uni } \\
\mathbf{t}\end{array}$} & \multicolumn{5}{|c|}{ Achievement } \\
\hline & & & & $\begin{array}{c}\text { Ja } \\
\text { n }\end{array}$ & $\begin{array}{c}\mathrm{Fe} \\
\mathbf{b}\end{array}$ & $\begin{array}{c}\text { Ma } \\
\mathbf{r}\end{array}$ & $\begin{array}{c}\text { Ap } \\
\mathbf{r}\end{array}$ & $\begin{array}{c}\mathrm{Ma} \\
\mathbf{y}\end{array}$ \\
\hline 1. & $\begin{array}{l}\text { Number } \\
\text { of client } \\
\text { complaint } \\
\mathrm{s} \text { in the } \\
\text { Inpatient } \\
\text { Unit }\end{array}$ & 12 & $\begin{array}{l}\mathrm{Ti} \\
\text { me }\end{array}$ & 0 & 0 & 0 & 0 & 0 \\
\hline 2. & $\begin{array}{l}\text { Timelines } \\
\text { s of } \\
\text { submitting } \\
\text { quality } \\
\text { target } \\
\text { reports } \\
\text { every } 15 \text { th } \\
\text { of each } \\
\text { month }\end{array}$ & 100 & $\%$ & 60 & $\begin{array}{c}10 \\
0\end{array}$ & $\begin{array}{c}10 \\
0\end{array}$ & $\begin{array}{c}10 \\
0\end{array}$ & $\begin{array}{c}10 \\
0\end{array}$ \\
\hline 3. & $\begin{array}{l}\text { Complete } \\
\text { ness of } \\
\text { client } \\
\text { status }\end{array}$ & 75 & $\%$ & 75 & 75 & 75 & 75 & 75 \\
\hline 4 & $\begin{array}{l}\text { Minimizin } \\
\mathrm{g} \text { errors in } \\
\text { giving } \\
\text { therapy }\end{array}$ & 0 & $\%$ & 0 & 0 & 0 & 0 & 0 \\
\hline 5 . & $\begin{array}{l}\text { Minimize } \\
\text { the risk of } \\
\text { falling on } \\
\text { the client }\end{array}$ & 0 & $\%$ & 0 & 0 & 0 & 0 & 0 \\
\hline 6. & $\begin{array}{l}\text { Complian } \\
\text { ce with } \\
\text { the use of } \\
\text { PPE }\end{array}$ & 75 & $\%$ & 75 & 75 & 75 & 75 & 75 \\
\hline 7. & $\begin{array}{l}\text { Hand } \\
\text { hygiene } \\
\text { complianc } \\
\text { e }\end{array}$ & 75 & $\%$ & 72 & 72 & 72 & 72 & 72 \\
\hline
\end{tabular}

Interview Summary, FGD, and Observations on the definition of Patient Safety were all FGD participants and 2 informants stated that Patient Safety was a service system to safe patients. While 3 informants stated that Patient Safety was a service system to safe patients with minimal risk and only 1 informant stated that Patient Safety was a way to make patients and officers comfortable and safe. At the time of observation, there was no written information about the definition of patient safety.

According to Informants at Ciracas Hospital, there is no Hospital Patient Safety Team (TKPRS) but there are officers in each unit who have the responsibility in implementing the 6 patient safety goals such as preventing patients falling, preventing infection, preventing patients from giving medication errors and so on, this officer called Champion Patient Safety (Table 3).

Table 3. Application of Patient Safety Goals

\begin{tabular}{|c|c|c|}
\hline Interview & FGD & Observation \\
\hline \multicolumn{3}{|c|}{ Definition of Patient Safety } \\
\hline $\begin{array}{l}\text { Efforts to prevent } \\
\text { patients from } \\
\text { being injured, } \\
\text { patients are safe, } \\
\text { comfortable with } \\
\text { minimal risk. }\end{array}$ & $\begin{array}{l}\text { Services to } \\
\text { patients who } \\
\text { are safe, } \\
\text { according to } \\
\text { instructions and } \\
\text { SPO. }\end{array}$ & $\begin{array}{l}\text { There is no written } \\
\text { information about } \\
\text { the definition of } \\
\text { Patient Safety in } \\
\text { the inpatient unit. }\end{array}$ \\
\hline \multicolumn{3}{|l|}{ PSGS } \\
\hline $\begin{array}{l}\text { FLS consists of six } \\
\text { targets, which } \\
\text { consisted of the } \\
\text { precision of } \\
\text { identity, effective } \\
\text { communication, } \\
\text { handling of human } \\
\text { rights (High Alert } \\
\text { Medication), just } \\
\text { the right procedure } \\
\text { patients, } \\
\text { prevention of } \\
\text { infection, and } \\
\text { decrease the risk } \\
\text { of falls. }\end{array}$ & $\begin{array}{l}\text { There are } 6 \\
\text { Standard } \\
\text { PSGS, effective } \\
\text { communication } \\
\text {, patient } \\
\text { identification, } \\
\text { tagging } \\
\text { operation, } \\
\text { preventive risk } \\
\text { patient falls, } \\
\text { medication use } \\
\text {-high alert } \\
\text { drug, } \\
\text { prevention of } \\
\text { infection } \\
\text { patients }\end{array}$ & $\begin{array}{l}\text { There is a banner } \\
\text { about Patient } \\
\text { Safety Goals. }\end{array}$ \\
\hline \multicolumn{3}{|c|}{ PSGS 1 Accuracy of Identity } \\
\hline $\begin{array}{l}\text { - The use of blue } \\
\text { patient identity } \\
\text { bracelets for men } \\
\text { and pink for women. } \\
\text { - Identity bracelets } \\
\text { contain two patient } \\
\text { identities. }\end{array}$ & $\begin{array}{l}\text { The give of } \\
\text { identity } \\
\text { bracelet to the } \\
\text { patient which } \\
\text { consists of the } \\
\text { name and date } \\
\text { of birth. }\end{array}$ & $\begin{array}{l}\text { There is an } \\
\text { identity bracelet } \\
\text { installed in the } \\
\text { patient according } \\
\text { to the patient's } \\
\text { gender. }\end{array}$ \\
\hline \multicolumn{3}{|c|}{ PSGS 2 Effective Communication } \\
\hline $\begin{array}{l}\text { Communication } \\
\text { with SBAR and } \\
\text { TBaK (Write Read } \\
\text { Confirmation) or } \\
\text { double check }\end{array}$ & $\begin{array}{l}\text { introduce } \\
\text { yourself to } \\
\text { patients every } \\
\text { shift, } \\
\text { orientation of } \\
\text { the place in } \\
\text { hospitalization, } \\
\text { explain the } \\
\text { bracelet to the } \\
\text { patient, and } \\
\text { explain the } \\
\text { patient's order }\end{array}$ & $\begin{array}{l}\text { There is a TBaK } \\
\text { stamp with writing } \\
\text { or } \\
\text { instruction/therapy } \\
\text { /action record in } \\
\text { CPPT }\end{array}$ \\
\hline
\end{tabular}




\begin{tabular}{|c|c|c|}
\hline \multicolumn{3}{|c|}{ PSGS 3 High Alert Drug Safety } \\
\hline $\begin{array}{l}\text { - There are } \\
\text { different controls } \\
\text { and placements for } \\
\text { High Alert/LASA } \\
\text { medicines } \\
\text { - For recording and } \\
\text { reporting there is a } \\
\text { special form of use } \\
\text { of the High Alert } \\
\text { drug }\end{array}$ & $\begin{array}{l}\text { There is a form } \\
\text { of use of the } \\
\text { High Alert } \\
\text { drug and } \\
\text { always re- } \\
\text { conform/doubl } \\
\text { e check for its } \\
\text { use }\end{array}$ & $\begin{array}{l}\text { Obtained Forms of } \\
\text { Use of High Alert } \\
\text { Medicines and red } \\
\text { bracelets for drug } \\
\text { allergy }\end{array}$ \\
\hline \multicolumn{3}{|c|}{ PSGS 5 Reducing Infection Risk } \\
\hline $\begin{array}{l}\text { To prevent infection } \\
\text { must do } 6 \text { steps of } \\
\text { hand washing } \\
\text { according to SPO } \\
\text { and } 5 \text { moments of } \\
\text { hand washing. }\end{array}$ & $\begin{array}{l}\text { Performing } 5 \\
\text { moments of } \\
\text { hand washing } \\
\text { and after using } \\
\text { handscoon }\end{array}$ & $\begin{array}{l}\text { - There are } 6 \text { steps } \\
\text { for handwashing } \\
\text { and } 5 \text { moments for } \\
\text { hand washing } \\
\text { - Hand scrub was } \\
\text { only at the door of } \\
\text { the inpatient room } \\
\text { - The soap in the } \\
\text { sink runs out. }\end{array}$ \\
\hline \multicolumn{3}{|c|}{ PSGS 6 Falling Risk Reduction } \\
\hline $\begin{array}{l}\text { - Patients were } \\
\text { assessed for the risk } \\
\text { of falling with Scale } \\
\text { Morse for adults and } \\
\text { the Humpty Dumpty } \\
\text { Scale for young } \\
\text { children } \\
\text { - Giving } \\
\text { markers/bracelets } \\
\text { for the risk of falling }\end{array}$ & $\begin{array}{l}\text { - Assessment } \\
\text { with Morse } \\
\text { Scale and } \\
\text { Humpty } \\
\text { Dumpty } \\
\text { - Giving a } \\
\text { yellow marker } \\
\text { for the risk of } \\
\text { falling }\end{array}$ & $\begin{array}{l}\text { Obtained SPO } \\
\text { patient risk } \\
\text { assessment and } \\
\text { Morse / Humpty } \\
\text { Dumpty Scale } \\
\text { form }\end{array}$ \\
\hline
\end{tabular}

Summary of interviews, FGDs, and observations on 6 PSGSs are all FGD participants and 3 informants know what PSGS stands for and consist of whatever PSGS is (PSGS 1-6). Two informants know what PSGS stands for and consists of, whatever the PSGS, even though it says it is not in line. Only one informant is unaware of the PSGS extension and what it entails. At the time of observation, there was a banner featuring six patient safety goals.

When the in-depth interview was conducted, not all informants knew of or had memorized the six PSGS, even though the PSGS extension did not know. During the FGD, however, most participants had memorized and knew the 6 PSGSs, only when they did not start from PSGS 1 to PSGS 6. Even though these participants passed the 2012 version of prime accreditation, some informants did not know what PSGS is (6 PSGS).

At the time of observation in the inpatient unit of Ciracas Hospital, a banner on Patient Safety Goals was obtained which consisted of everything from PSGS 1-6 but this banner was only 1 and often moved places sometimes in the ED, inpatient unit, lobby, and hall. This banner is not just an inpatient unit inventory but can move places depending on their needs because this banner was created only for accreditation survey purposes.

\section{Discussion}

Patient Safety is a way to prevent errors and side effects to patients related to health services (WHO) or patient safety is an effort to prevent injury to patients $[3,13]$.

Hospital's patient safety is a system where the hospital makes patient care safer [3, 14]. The system includes: assessing risk, identifying and managing matters related to patient risk, incident analysis, and reporting, learning abilities from incidents and follow-up and implementation of solutions to minimize risk [15]. The system is expected to prevent the occurrence of injury caused by errors due to carrying out an action or not taking action that should be done [16].

According to the results of the study concluded that what is meant by patient safety or patient safety is a system/method of patient care that is safe, comfortable with minimal risk. Although there are still differences in words in interpreting the definition of patient safety/patient safety if it is concluded this statement is in line with the explanation from WHO and IOM that patient safety is an effort to prevent side effects, errors, and injuries to patients related to health services $[12,13$, 17].

Information about patient safety in the inpatient unit is minimal because there is no other written information found. Information on patient safety should be reproduced more and should not only be oral but written will be better $[18,19]$. This information can be in the form of banners, posters, multimedia (patient safety promotional videos) or other information related to the definition of patient safety so that both officers and patients/family/visitors of the inpatient unit will always be able to read and at least understand first what is meant by patient safety [20].

Under the Minister of Health Regulation No. 1691 of 2011, PSGS is a standard that must be met by every hospital so that the purpose of hospital accreditation can be achieved, one of which is improving the safety of hospital patients [21]. In Ciracas Hospital, which has passed the 2012 version of RS Accreditation and has undergone the first verification, there are still those who do not know what this PSGS stands for and consist of what PSGS is where the knowledge is the most basic knowledge that must be known before applying PSGS. This shows that there is still a lack of socialization regarding PSGS in Ciracas Hospital, this can be seen from the lack of information about PSGS/patient safety, especially in inpatient units.

In addition, factors of behavior and mindset of Ciracas Hospital HR in the works also have a significant influence in the implementation of the FLS, such as that delivered by the Health and Safety Commissions Advisory Committee on the Safety of Nuclear Installations in 1993 that Safety Culture in an organization is the result of individual and group values, behavior, perceptions, competencies, and behavioral patterns that demonstrate overall commitment to organizational health and safety management. 


\section{Conclusion}

Information or knowledge about patient safety must be known by every employee/HR who works in Ciracas Hospital starting from Cleaning Service to the Top Management level. Sufficient knowledge about patient safety will determine how the system implemented or implemented in Ciracas Hospital to support or succeed in Patient Safety Program especially the application of PSGS in the Ciracas Hospital Inpatient Unit.

This study shows an overview of the Standard PSGS Application in the Inpatient Unit of Ciracas Hospital after the accreditation survey by KARS and in general it can be concluded that although Ciracas Hospital has passed as the Special Accreditation Program Hospital on 2012 version it does not guarantee the application of PSGS in the Ciracas Hospital Unit has well-proceeded.

\section{Conflict of Interest}

The authors have declared that no competing interests exist.

\section{Acknowledgment}

This study was funded by the Directorate for Research and Community Development, University of Indonesia. We would like to thank all parties: all staff and lecturers of Hospital Administration Studies, Faculty of Public Health, University of Indonesia.

\section{References}

1. M.S. Donaldson J.M. Corrigan, L.T. Kohn LT, To Err is Human: Building a Safer Health System, National Academies Press 6, (2000)

2. W. Wischet, C. Schusterschitz, Quality Management and Safety Culture In Medicine - Do Standard Quality Reports Provide Insights into The Human Factor of Patient Safety?, GMS Ger Med Sci 15(7) (2009)

3. C. Vincent, R. Amalberti Progress and Challenges for Patient Safety BT - Safer Healthcare: Strategies for the Real World. Cham: Springer International Publishing. 1-12 (2016)

4. Indonesian Department of Health, National Hospital Patient Safety Guide (patient safety), Jakarta: PERSI-KKPRS (2008)

5. M.J.O. Lopez, New Initiatives to Improve Medication Safety in Hospitals, Rev. Esp. Salud. Publica. 78(3), 323-39 (2004)

6. Institute for Safe Medication Practices, Pathways for Medication Safety - Leading a Strategic Planning Effort, Institute for Safe Medication Practices (2002)

7. C. Hospital, Strategic Plan of Ciracas General Hospital, Jakarta (2015)

8. C. Hospital, Feasibility Study of Ciracas General Hospital, Jakarta (2015)
9. PerGub DKI Jakarta, Governor Regulation No. 128 of 2014 concerning Establishment of Organizations and Work Procedures for Class D General Hospitals, Jakarta: Pemerintah DKI Jakarta 128 (2014)

10. PerGub DKI Jakarta, Governor Regulation No. 1024 of 2014 concerning Determination of District Health Centers to become Class D General Hospitals, Jakarta: Pemerintah DKI Jakarta 1024 (2014)

11. Ministry of Health - Republic of Indonesia, Regulation of the Minister of Health No. 1691 of 2011 concerning Hospital Patient Safety, Indonesia: Ministry of Health - Republic of Indonesia 1691 (2011)

12. WHO Patient Safety, The Conceptual Framework for the International Classification for Patient Safety (ICPS), Geneva: World Health Organization, 1-153 (2010)

13. S. Bleich, Medical errors: five years after the IOM report. In: Issue Brief, Commonw Fund, 1-15 (2005)

14. A. Asyary, H, Kusnanto, A. Fuad, Computerized Physician Order Entry on Patient Medication Safety, J. Kesehat. Masy. Nas. 8(23), 125-132 (2013)

15. J-H. Kang, C-W. Kim, S-Y. Lee, Nurse-perceived Patient Adverse Events and Nursing Practice Environment, J. Prev. Med. Public Heal. 47(5), 273-280 (2014)

16. Chief Medical Officer, An organization with a Memory. Report of an Expert Group on Learning from Adverse events in the NHS, London: HMSO (2000)

17. A. Abdellatif, J.P. Bagian, E.R. Barajas, M. Cohen, D. Cousins, et al., Communication During Patient Hand-Overs, Jt. Comm. J. Qual. Patient Saf. (2007)

18. M. Randmaa, Communication and Patient Safety: Transfer of Information between Healthcare Personnel in Anaesthetic Clinics, Acta Universitatis Upsaliensis (2016)

19. I. Mitchell, A. Schuster, K. Smith, P. Pronovost, A. Wu, Patient Safety Reporting: A Qualitative Study Of thoughts and Perceptions of Experts 15 Years After 'To Err Is Human, BMJ Qual. Saf.. (2015)

20. M. Ock, S.Y. Lim, M-W. Jo, S. Lee, Frequency, Expected Effects, Obstacles, and Facilitators of Disclosure of Patient Safety Incidents: A Systematic Review, J. Prev. Med. Public Heal 50(2), 68-82 (2017)

21. Ministry of Health - Republic of Indonesia. Regulation of the Minister of Health of the Republic of Indonesia Number 1691 / MENKES / PER / VIII / 2011 concerning Hospital Patient Safety, Indonesia: Ministry of Health - Republic of Indonesia (2011) 